\title{
Construction Project Accounting System based on the Earned Value Management and Management Accounting Framework in Road and Bridge Project
}

\author{
[Josefine Ernestine Latupeirissa, Irwan Lie K W]
}

\begin{abstract}
The main function of the accounting system is to encourage optimal as possible so that the system can generate a variety of structured accounting information that is timely, relevant, and trustworthy. The elements contained in an accounting system are related to each other, so do the data processing from the initial transaction to reporting that can be used as accounting information. The accounting system for the contractor depends on the condition of each contractor and characteristics of projects handled. The accounting system and its relation with Earned Value Management (EVM) started from the project planning phase to the control of the project implementation. The accounting system used to process all transactions that occur both inside and outside the project. Project accounting system is part of a project control. The accounting system is used primarily to obtain data ACWP and BCWP used for the calculation of the performance with the concept of earned value. While Managerial Accounting Framework (MAF) is used internally by managers and employee teams for decision making. In this research, the accounting system implemented by the contractor is using the cash method that is the cash in-cash out when the transaction occurs. After doing a combination of the methods applied by the contractor, with the method of EVM and MAF, then produced a comprehensive formula, so that the accounting system to be more systematic
\end{abstract}

Keywords- Accounting System, Earned Value Management, Management Accounting Framework, Construction Project

\section{Introduction}

According Mulyadi (2001), that the accounting system is an organization of forms, records, and reports are coordinated in such a way as to provide financial information that facilitates management in order to facilitate the management of the company. The accounting system construction project is part of the project cost control (Cost Control). In the implementation of road and bridge construction projects application accounting system depends on each project executor.

Latupeirissa Josefine Ernestine

Universitas Kristen Indonesia Paulus

Makassar-South Sulawesi-Indonesia

Irwan Lie K W

Universitas Kristen Indonesia Paulus

Makassar-South Sulawesi-Indonesia
The accounting system is used primarily to obtain data ACWP and BCWP used for the calculation of the performance with the concept of earned value. While Lalli, (2003) said that Managerial Accounting Framework (MAF) is used internally by managers and employee teams for decision making. The accounting system applied to contractors in construction projects, especially the construction or improvement of roads and bridges, depending on the condition of each contractor and the characteristics of the project.

\section{Project cost management (PMBOK GUIDE, 2008).}

Project Cost Management includes the processes involved in estimating, budgeting and controlling costs so that the project can be completet within the approved budget

On some projects, especially ones of smaller scope, cost estimating and cost budgeting are so tightly linked that they are viewed as a single process that can be performed by a single person over a relatively short period of time. The cost management plan may be formal or informal, highly detailed or broadly framed, based upon the needs of the project.

Project cost management should consider the stakeholder requirements for capturing costs. Different stakeholder will measure project costs in different ways and at different time. Project cost management is primarily concerned with the cost of the resources needed to complete project activities. Project cost management should also consider the effect of project decisions on the subsequent recurring cost of using, maintaining, and supporting the product, service, or result of the project.

The cost management planning effort occurs early in project planning and sets the framework for each of the cost management processes so the performance of the processes will be efficient and coordinated

\section{A. Cost Estimatings}

Estimate cost is the process of developing an approximation of the monetary resources needed to complete project activities. Cost are estimated for all resources that will be charged to the project. This includes, but is no limited to, labor, materials, equipment, services and facilities, as well as special categories such as an 
inflation allowance or contingency cost. A cost estimate is a quantitative assessment of the likely costs for resources required to complete the activity.

Estimated cost detail consists of two components (AACE, 1992) as shown in Figure 1 below:

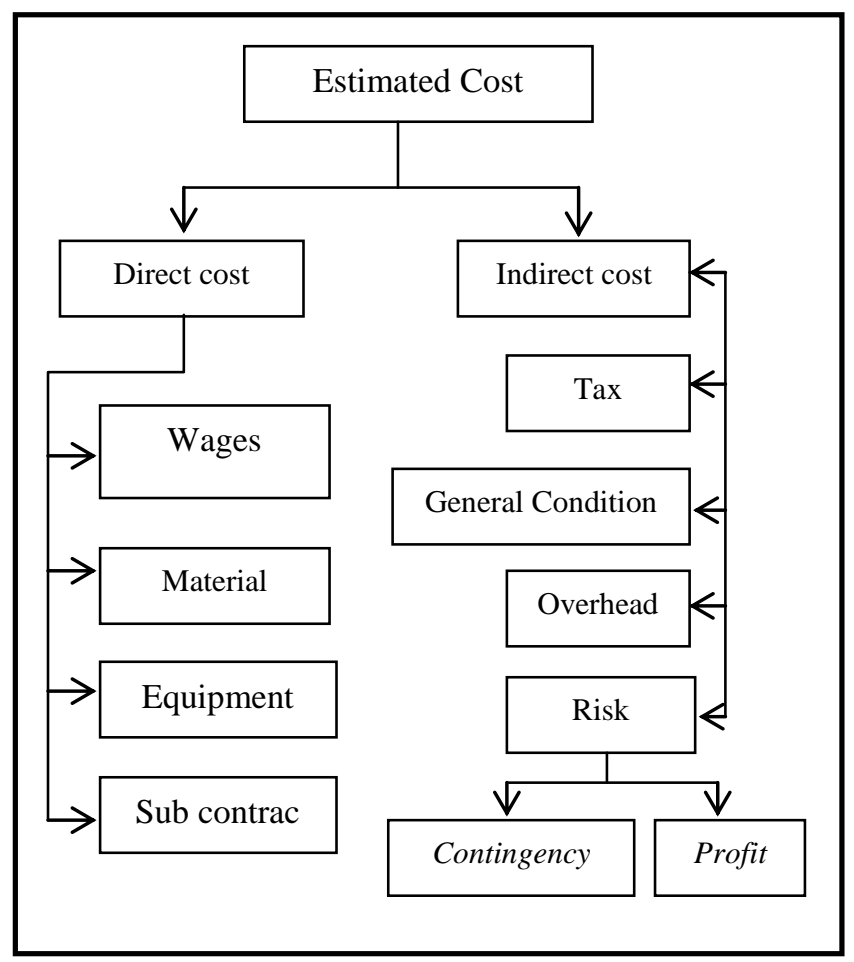

Figure 1. Estimated cost detail consists of two components (AACE, 1992)

\section{B. Cost Budgeting}

Determine Budget is the process of aggregating the estimated costs of individual activities or work packages to establish an authorized cost baseline. This baseline includes all all authorized budgets, but excludes management reserves. Projects budgets constitute the fund authorized to execute the project. Project cost performance will be measured against the authorized budget.

\section{Cost Controlling}

Control Costs is the process of monitoring the status of the project to update the project budget and managing changes to the cost baseline.

Earned value management (EVM) in its various forms is a commonly used method of performance measurement. It integrates project scope, cost, and schedule measures to help the project management team assess and measure project performance and progress. It is a project management technique that requires the formation of an integrated baseline against which performance can be measured for the duration of the project. The principles of EVM can be applied to all projects, in any industry. EVM develops and monitors three key dimensions for each work package and control account:

Planned value. Planned value (PV) is the authorized budget assigned to the work to be accomplished for an activity or work breakdown structure component. It includes the detailed authorized work, plus the budget for such authorized work, allocated by phase over the life of the project. The total of the PV is sometimes referred to as the performance measurement baseline (PMB). The total planned value for the project is also known as Budget At Completion (BAC).

Earned value. Earned value (EV) is the value of work performed expressed in terms of the approved budget assigned to that work for an activity or work breakdown structure component. It is the authorized work that has been completed, plus the authorized budget for such completed work. The EV being measured must be related to the PV baseline (PMB), and the EV measured cannot be greater than the authorized PV budget for a component. The term $\mathrm{EV}$ is often used to describe the percentage completion of a project. A progress measurement criteria should be established for each WBS component to measure work in progress. Project managers monitor $\mathrm{EV}$, both incrementally to determine current status and cumulatively to determine the long-term performance trends.

Actual cost. Actual cost (AC) is the total cost actually incurred and recorded in accomplishing work performed for an activity or work breakdown structure component. It is the total cost incurred in accomplishing the work that the EV measured. The AC has to correspond in definition to whatever was budgeted for in the PV and measured in the EV (e.g., direct hours only, direct costs only, or all costs including indirect costs). The AC will have no upper limit; whatever is spent to achieve the EVwill be measured.

\section{Accounting System}

Wikipedia Indonesia (2016) states that the accounting system is the methods and procedures for recording and reporting of financial information provided to the company or a business organization. The accounting system applied in large enterprises is very complex. The complexity of the system caused by the specificity of a system designed for a business organization as a result of differences in the need for information by the manager, both the model and the transaction's financial

To be effective, a report presented by the accounting must be made in a timely, clear and consistent. The report presented by the knowledge and needs of users in order to be used as consideration in decision making. Implementation of the system is not only the responsibility of the existing personnel in certain parts, but all personnel should be responsible for the operation of the system. Operation of the system must be carefully and always carried out supervision of the system before it is operated entirely.

\section{Research Methodology}

The study was conducted in three provinces in eastern Indonesia, which includes 33 contractors on provinces A, 32 contractors on provincial $\mathrm{B}$ and by 47 companies on provinces $\mathrm{C}$. Contracting company that became the object of research is a contractor who is carrying out and has completed construction or improvement of roads and bridges. Identification is performed to determine how the application of the accounting system in the construction or improvement projects. Some of the ways or methods can be applied by the contractor include: accounting systems contracting company itself, and / or accounting system based accounting system that is commonly used in 
accounting such as Management Accounting Framework (MAF) and/or Earned Value Management System (EVMS ).

\section{A. Accounting Systems Contractors}

The accounting system contractors depending on the conditions the contracting company itself and the characteristics of road and bridge project that upgraded or new built. To find out the accounting system is applied then the data source is needed is a secondary data and primary data as shown in Table 1. below:

\begin{tabular}{|l|l|l|}
\hline \multicolumn{4}{|c|}{ TABLE 1. SECONDARY AND PRIMARY DATA } \\
\hline No & $\begin{array}{c}\text { Type of } \\
\text { Data }\end{array}$ & \multicolumn{1}{c|}{ Description } \\
\hline 1. & Secondary & 1.Contract documents \\
\hline & & 2. Master schedule \\
\hline & & 3. Daily report \\
\hline 2. & Primary & $\begin{array}{l}\text { 1. The questionnaire, which contained questions in } \\
\text { the questionnaire format that has been } \\
\text { developed systematically. Questions in the } \\
\text { questionnaire aims to obtain information about } \\
\text { the model accounting system applied } \\
\text { contractor in the project and how the } \\
\text { integration of these systems with the } \\
\text { company's accounting system after conducting } \\
\text { an analysis of secondary }\end{array}$ \\
\hline & $\begin{array}{l}\text { 2. Interviews addressed to the manager (or } \\
\text { equivalent) or decision-makers. The format of } \\
\text { the interview contains questions similar to the } \\
\text { format of the questionnaire }\end{array}$ \\
\hline
\end{tabular}

\section{B. Accounting System according to handbook of budgeting}

Lalli (2003) says that the accounting system consists of a system of financial accounting and managerial accounting system. At the highest level of managerial accounting there are two broad elements : measuring the costs and using the cost data, as shown in Figure 2. which displays an overarching framework for managerial accounting with a tree, branch, and leaf" structure. In this framework each branch can be further separated into the following key components :

Cost measurement. Measuring costs comprises collecting data and assigning the source expenses in a way that is meaningful for the organization

Cost uses . Many managerial accounting textbooks will usually state that there are three broad purposes for using cost data : operational control, assessment and evaluation, and predictive planning

The first two uses, operational control and assessment, are less challenging for cost accounting. This is because descriptive of history. Refer to them as "cost autopsies". The money was spent. There is no debate about that but rather where the money was spent. So the only accounting task is to focus on rules of trace ability. But with the third view, predicting future expense.

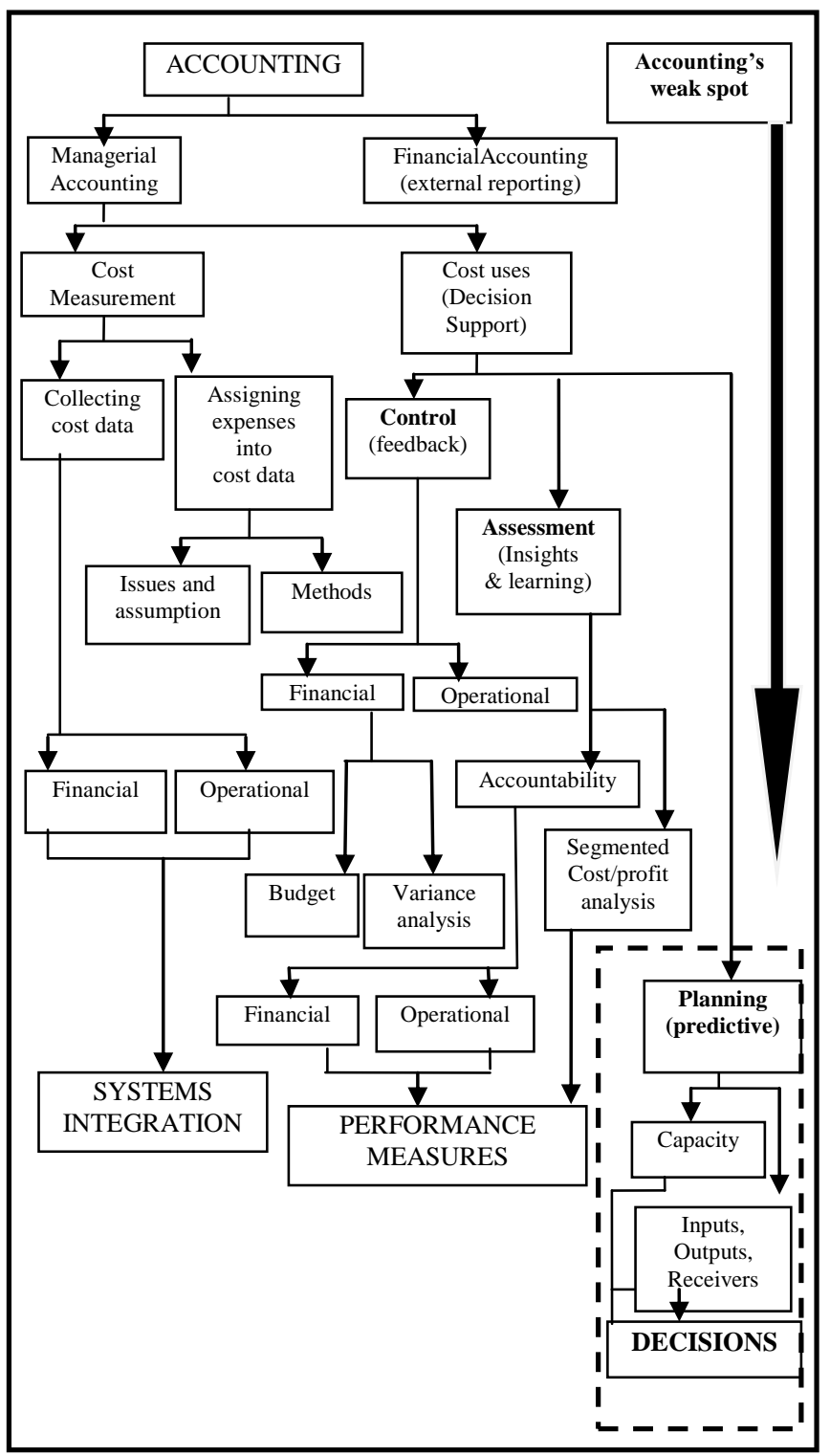

Figure 2. Management accounting framework (Lalli, 2003)

\section{Earned value management system (EVMS)}

The accounting system and its relation with the Earned Value Management System (EVMS) starting from the planning phase of a project to control the implementation of the project. EVMS working process is shown in Figure 3. The purpose of this review is to ensure the ability to manage cost, schedule, and performance of the project.

EVM relies on three key data point : Planned Value, Earned Value, and Actual Cost.

Planned Value (PV) describes how far along project work is supposed to be at any given point in the project schedule. Also known as the Budgeted Cost of Work Scheduled (BCWS), PV is usually charted showing the cumulative resources budgeted across the project schedule. 
- $\quad$ Earned Value (EV) is a snapshot of work progress at a given point in time. Also known as the Budgeted Cost of Work Performed (BCWP), it reflects the amount of work that has actually been accomplished to date (or in a given time period), expressed as the planned value for the work.

Actual Cost (AC), also known as the Actual Cost of Work Performed (ACWP), is an indication of the level of resources that have been expended to achieve the actual work performed to date (or in a given time period)

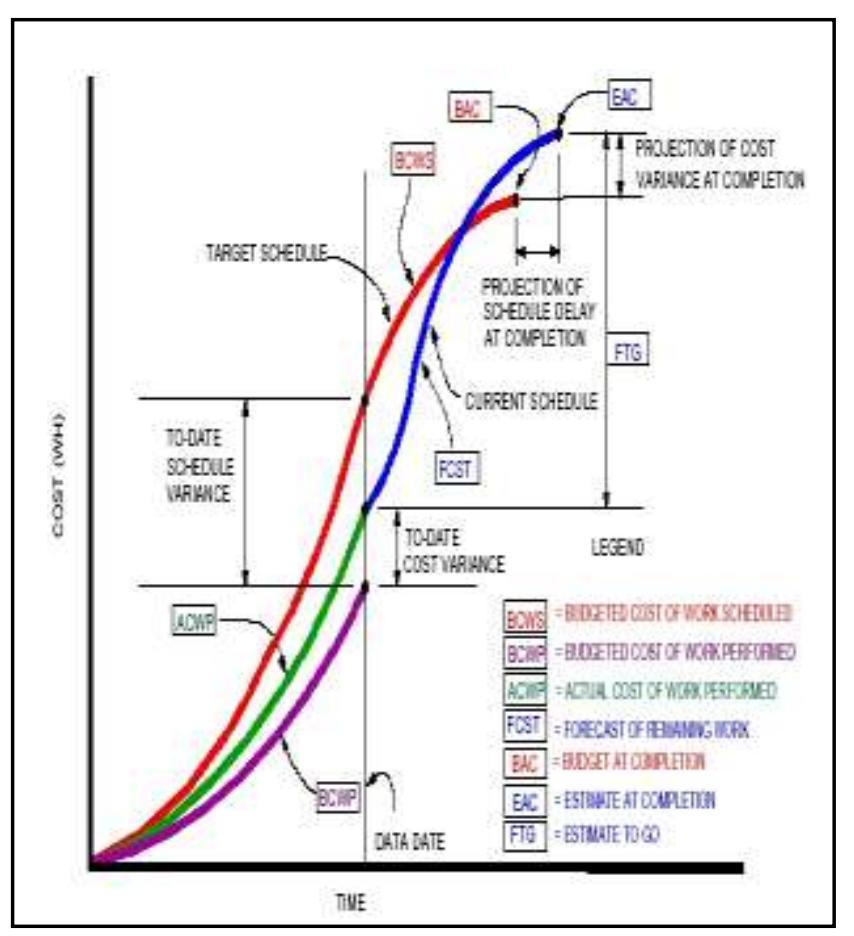

Figure 3. Earned Value Diagram

\section{v. Analysis and Discussion}

\section{A. Analysis}

\section{1) Primary and secondary data analysis}

The observations show that the method used is the general contractor in which the cash method of accounting systems recognize transactions when the flow of money. (Cash in-cash out). The Contractor shall record the transaction in accordance with the order and the date of the activities and groupings. General contractors not directly record or perform bookkeeping when the transaction occurs.. This resulted in the contractor fails to control measures, in case of deviation from the time and cost plans..

Recording of transactions include transactions: labor costs, material costs, equipment costs to suppliers and indirect costs. While contractors receive payment from the owner in accordance with the contractual agreements are appropriate percentage of the progress of work has been agreed or based on the volume of work that has been achieved. Contractors do not have a standard procedure or fixed that can be used as a standard operating procedure in the accounting system applied.

Further mapping of secondary data obtained from contractors . Mapping results verified by conducting interviews and questionnaires that can provide clearer information of how the application of the accounting system of in the implementation of the project.

Construction project accounting system of implemented on roads and bridges projects in the three areas following the flowchart as Figure 4 below:

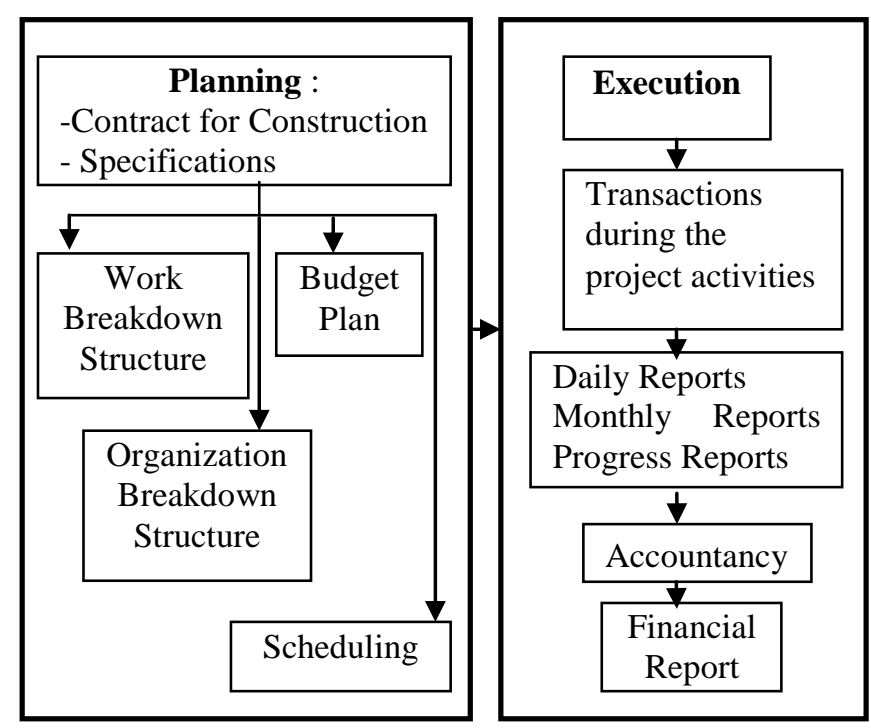

Figure 4. Construction project accounting system of contractor

\section{2) Accounting system development road and bridge construction projects based on the EVM and MAF}

Analysis of the accounting system which is implemented in road and bridge project as shown in Figure 4 shows that expenditures to finance the direct costs and indirect costs are not proportional to the progress of work. This is due to financial transactions carried out not by the progress of work. Thus, if there are deviations to the implementation schedule, the contractor is not able to immediately detect it to exercise control. This is the problem that makes the construction projects is often delayed.

Based on Figure 4 above, attempted to establish the accounting system construction projects, especially the construction or improvement of roads and bridges by doing a collaboration with the accounting system based on the MAF in Figure 2 and the accounting system based EVM in Figure 3. Thus, the model of development of accounting systems that can be applied to projects proposed for road and bridge construction is as shown in Figure 5 below: 


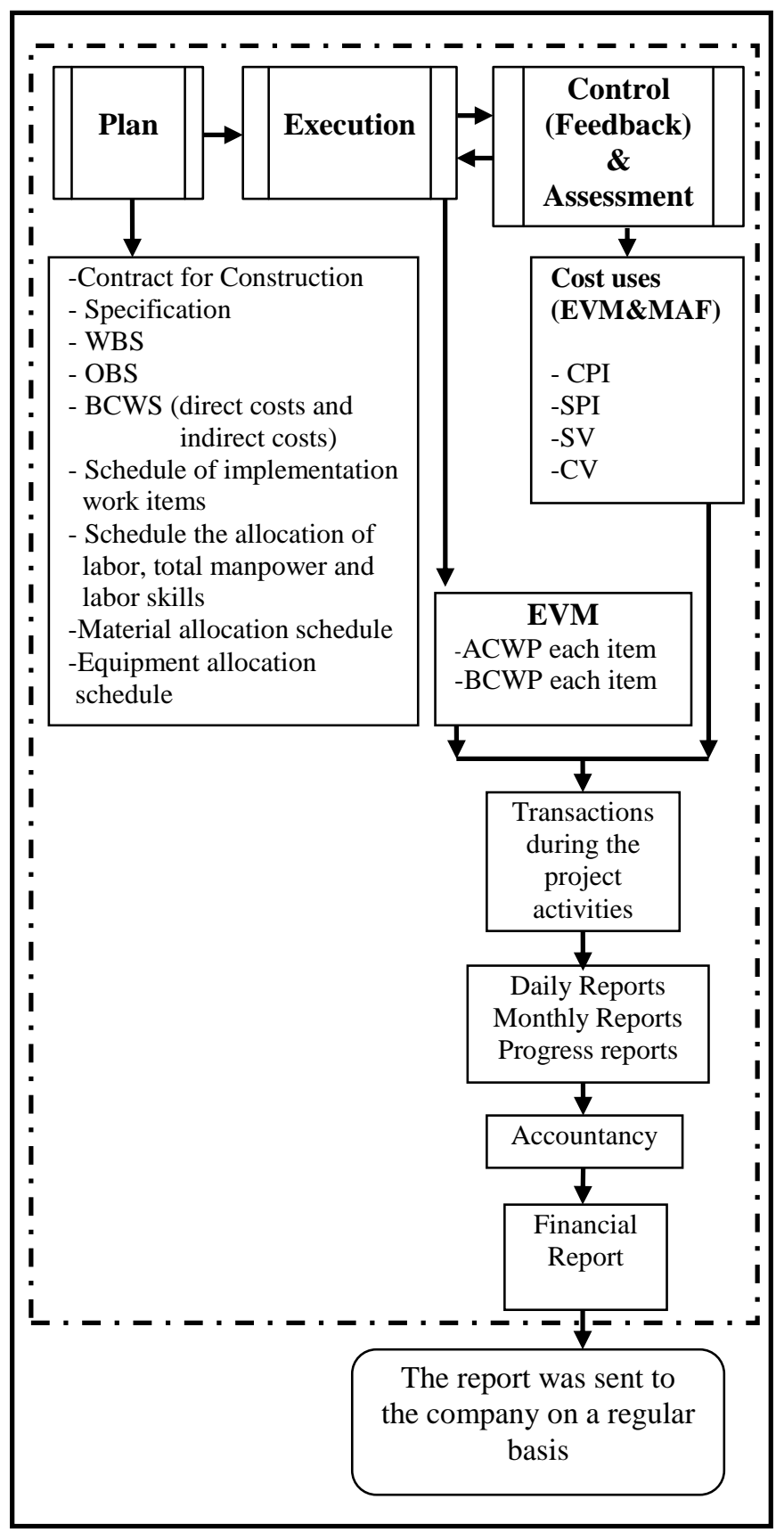

Figure 5. Accounting system development road and bridge construction projects based on the EVM and MAF

\section{B. Discussion}

The accounting system has started the planning phase. In this phase, the overall cost estimate done by the contract documents and specifications that take into account the cost of direct and indirect costs (Figure 2). The function of the accounting system is to report the transaction costs incurred and as a means of controlling costs. Furthermore, in the implementation phase where absorption occurs very large fund, evaluation, corrective action and control continuously based on the progress of each activity.
Actual expenses incurred are summarized in a complete and accountable so that it can be clearly seen actual costs incurred during the project.

The application of a combination of EVM and MAF to improve the accounting system that has been done in the implementation of the project can be as early warning devices to the project implementers to be able to take decisions quickly.

\section{Acknowledgment}

This research was supported by the Ministry of Research, Technology and Higher Education of Indonesia for research grants in fiscal year 2016. Therefore, the authors are grateful and thank you very much.

\section{References}

[1] AACE, (1992) :"Skills \& Knowledge of Cost Engineering". Third Edition, AACE Inc.

[2] Bappenas (2003): “ Perencanaan Pembangunan Nasional”, Bappenas TA-SRPP, Jakarta.

[3] Baridwan,Zaki, (2012) : "Intermediate Accounting", Edisi Kedelapan, Badan Penerbit FE-UGM, Yogyakarta

[4] Choi, Frederick D S and Meek Gary K (2011) : "International Accounting", Seventh Edition. Pearson. Prentice Hall

[5] Flemming, Q. W., Koppelman, J. M : "The Essence and Evoluation of Earned Value", AACE Transaction. 1994

[6] James Thoengsal (2015) : "Pengendalian Waktu Dan Biaya Dengan Menggunakan Metode Earned Value Management (EVM) (Kasus Pelaksanaan Proyek Peningkatan Jalan Trans Yamdena Tumbur Kabupaten Maluku Tenggara Barat). Tesis Magister Teknik Sipil. Universitas Kristen Indonesia Paulus

[7] Jefferson Science Associates, LLC.:"Earned Value Management System".GuidelinesComplaince.www.jlab,org/div.dept/direct orate/proj

[8] Lalli, William R (2003) : “ Handbook of Budgeting. Fifth Edition. John Wiley\&Sons, Inc

[9] Latupeirissa, J. E and Jonie Tanijaya : "Evaluasi Kinerja Waktu Pelaksanaan Proyek Jalan dan Jembatan di Indonesia Timur", Seminar Nasional Teknik Sipil ke 8 (KonTekS8), ITENAS BandungIndonesia 16-17 October 2014

[10] Latupeirissa, J. E :" Earned Value Management(EVM) on Controlling the Implementation of the Road Construction Project". International Journal of Civil\&Sructural Engineering (IJCSE). Volume 3, Issue 1/ 18 April 2016

[11] Mulyadi. 2008 : “ Sistem Akuntansi”, Edisi ketiga, Cetakan Keempat, Salemba Empat, Jakarta

[12] Project Management Institute, Inc (2005) : Practise Standard for Earned Value Management", Publish by Project Management Institute, Pennsylvania. USA

[13] National Defense Industrial Association (NDIA) Program Management Systems Committee (PMSC) ANSI/EIA-748-A : Standard for Earned Value Management Systems Intent Guide. National Defense Industrial Association . Januari 2006

[14] Project Management Institute, Inc (2008) : Body of Knowledge", Publish by Project Management Institute. Pennsylvania. USA

[15] Soemardi, B.W., Wirahadikusumah, R.D., Abduh, M : "Konsep Earned Value untuk Pengelolaan Proyek Konstruksi. Jurnal Ilmiah. Bandung- Indonesia.2006

[16] Wikipedia Indonesia (2016) : “Akuntansi”. Ensiklopedia Bebas. Download date 04 Juli 2016. 